\title{
PERANCANGAN SISTEM INFORMASI MANAJEMEN BERBASIS KOMPUTER GUNA MENINGKATKAN PELAYANAN PADA BAGIAN APOTIK DI RSU KEPANJEN - MALANG
}

\author{
Annisa Kesy $\mathbf{G}^{\mathbf{1}}$, Nanang Dwi Irhandi ${ }^{2}$
}

\begin{abstract}
For this time, preparation of information technology be in the process of revolution or big change precisely. Such was the case with the Apotik of RSU Panggung Kepanjen - Malang, which acceptance recipe system and the information process of medicines for consumer or for own hospital side still not make ose of management information system which use computer yet, with the result that, make it difficult for several side to processing a lot of data become an information.

With this situation, then we hope that there is some design system to reach information which have speedy, accuration, and appropriacity as principal factor for collecting and processing a lot of data.

This task in order to design some management information system which computer basicly with use aplication of Foxpro for Windows software to processing data faster and increasing activity efficiency with the result that can be raise attendant time of apotik staff.

Base of analys result, can be known that attendant time before SIM application is 11.7 minutes for 1 recipe / 1 medicinie, while that, the attendant time after SIM application is 6.51 minutes for 1 recipe / 1 medicine. And base on hipotesm test for two average difference test : one side, then can be known that the purpose of computer software is indeed to concise the attendant time of apotik staff.
\end{abstract}

\section{Key Words : Queuing, Attendant Time, Management Information System}

\section{PENDAHULUAN}

Dewasa ini pengolahan teknologi informasi sedang mengalami revolusi atau perubahan yang cukup besar. Demikian halnya yang terjadi di apotik RSU Kepanjen Kab. Malang, dimana sistem pemasukan, pemrosesan dan penyimpanan data yang ada masih belum menggunakan suatu sistem informasi yang terkomputerisasi (manual) sehingga menghambat pihak yang terkait dalam pengolahan data menjadi suatu informasi. Hal tersebut mengakibatkan terlambatnya pencatatan order, transaksi jenis barang dan keterlambatan di dalam pemberian pelayanan kepada konsumen Dengan demikian diharapkan bahwa dengan adanya penerapan sistem informasi manajemen berbasis komputer ini, maka tidak ada konsumen yang terpaksa harus pergi ke apotik lain karena obat yang dimaksud tidak tersedia. Disamping itu, jika dari data-data yang akurat diketahui ternyata ada beberapa jenis obat yang sering dibeli oleh konsumen dan ada beberapa jenis obat yang jarang dibeli, maka pihak apotik rumah sakit dapat merencanakan dan mengendalikan jumlah stock yang tepat agar jenis obat yang dimaksud selalu tersedia. 


\section{TINJAUAN PUSTAKA}

\section{Sistem jasa}

Pengertian sistem jasa adalah usaha yang dijalani untuk merubah masukan-masukan (input) sumberdaya untuk menciptakan atau menghasilkan suatu jasa pelayanan (output) yang bermanfaat.

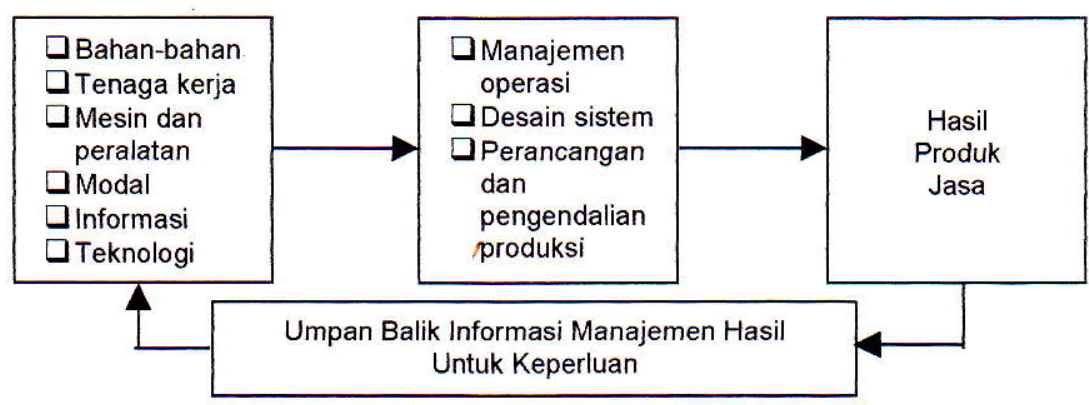

Gambar 1

Bagan Manajemen Operasi

[Davis B.Gordon ; 1998 ; 2$]$

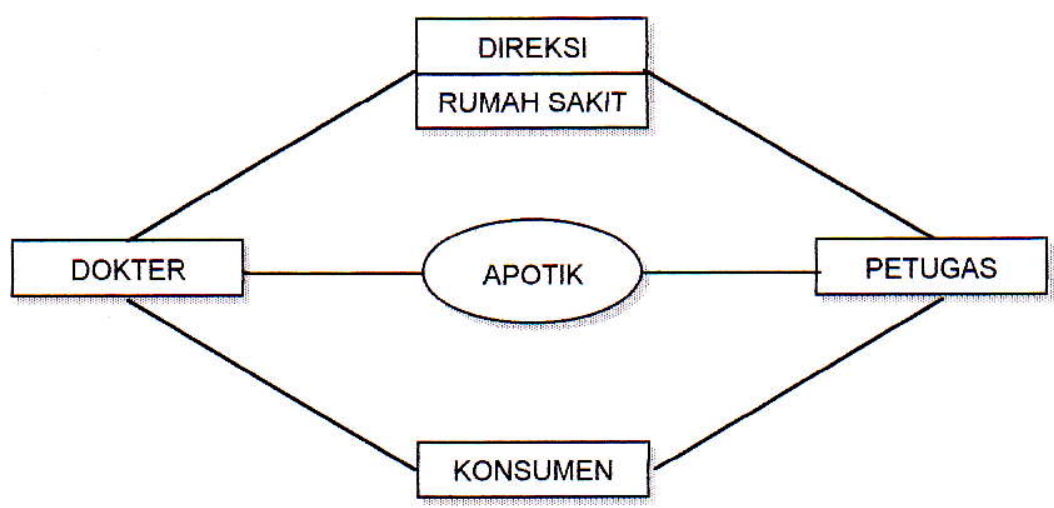

Hubungan Antar Elemen Dalam

\section{Sistem Informasi Manajemen}

Sistem Informasi Manajemen merupakan suatu sistem yang terintegrasi, ditopang oleh komputer, terjadi interaksi user-machine yang menghasilkan informasi yang dibutuhkan dengan cepat, tepat dan akurat untuk mendukung fungsi operasi dan pengambilan keputusan.

\section{Tujuan Sistem Informasi Manajemen}

口 Meningkatkan accesbility data yang tersaji secara tepat waktu dan akurat 
- Meningkatkan efisiensi operasional organisasi

- Menetapkan investasi yang akan diarahkan pada sistem informasi

口 Peningkatan kreasi/improvisasi terhadap produk/jasa yang dihasilkan.

\section{Pengujian Hipotesis}

Hipotesis adalah asumsi atau dugaan mengenai sesuatu hal yang dibuat untuk menjelaskan hal itu yang sering dituntut untuk melakukan pengecekannya.

Untuk pengujian hipotesis penelitian, dilakukan pengambilan sampel acak, nilai-nilai statistik yang perlu dihitung kemudian dibandingkan dengan menggunakan kriteria tertentu. Jika hasil yang didapat dari peneltian itu jauh berbeda dari hasil yang diharapkan terjadi berdasarkan hipotesis, maka hipotesis ditolak. Jika terjadi sebaliknya, hipotesis diterima.

\section{Uji Selisih Dua Rataan : Uji Satu Pihak}

Sebagaimana dalam uji dua pihak, untuk uji satu pihak pun dimisalkan bahwa kedua populasi berdistribusi normal dengan rata-rata $\mu_{1}$ dan $\mu_{2}$ dengan simpangan baku $\sigma_{1}$ dan $\sigma_{2}$. Karena umumnya besar $\sigma_{1}$ dan $\sigma_{2}$ tidak diketahui, maka di sini akan ditinjau hal-hal tersebut untuk keadaan $\sigma_{1}=\sigma_{2}$ atau $\sigma_{1} \neq \sigma_{2}$. Disamping itu, karena simpangan baku $\sigma$ pada umumnya tidak diketahui, maka dipergunakan taksirannya (s), baik untuk $\mathrm{s}_{1}$ maupun $\mathrm{s}_{2}$ sebagai berikut :

$$
\mathrm{s}^{2}=\frac{\sum\left(\mathrm{x}_{\mathrm{i}}-\overline{\mathrm{x}}\right)^{2}}{\mathrm{n}-1}
$$

[Prof.DR.Sudjana,M.A.M.Sc ; $1992 ; 93]$

\section{Uji Pihak Kanan}

$$
\begin{cases}\mathrm{H}_{0}: & \mu_{1}=\mu_{2} \\ \mathrm{H}_{1}: & \mu_{1}>\mu_{2}\end{cases}
$$

Dalam hal $\sigma_{1}=\sigma_{2}$, maka statistik yang digunakan ialah statistik t sebagai berikut :

$$
t=\frac{\bar{x}_{1}-\bar{x}_{2}}{s \sqrt{\frac{1}{n_{1}}+\frac{1}{n_{2}}}}
$$

dengan $\mathrm{s}^{2}$ sebagai berikut :

$$
\mathrm{s}^{2}=\frac{\left(\mathrm{n}_{1}-1\right) \mathrm{s}_{1}^{2}+\left(\mathrm{n}_{2}-1\right) \mathrm{s}_{2}{ }^{2}}{\mathrm{n}_{1}+\mathrm{n}_{2}-2}
$$

Kriteria pengujian yang berlaku adalah : terima $\mathrm{H}_{0}$ jika $\mathrm{t}<\mathrm{t}_{1}-\alpha$ dan tolak $\mathrm{H}_{0}$ jika $t$ mempunyai harga-harga lain. Derajat kebebasan untuk daftar distribusi $t$ ialah $\left(\mathrm{n}_{1}\right.$ $\left.+n_{2}-2\right)$ dengan peluang $(1-\alpha)$. Jika $\sigma_{1} \neq$ $\sigma_{2}$, maka statistik yang digunakan adalah statistik t' seperti dalam rumus berikut :

$$
t^{\prime}=\frac{\bar{x}_{1}-\bar{x}_{2}}{\sqrt{\frac{s_{1}^{2}}{n_{1}}+\frac{s_{2}^{2}}{n_{2}}}}
$$

dalam hal ini kriteria pengujian adalah tolak hipotesis $\mathrm{H}_{0}$ jika

$$
t^{\prime} \geq t_{\text {tabel }}
$$

dan terima $\mathrm{H}_{0}$ jika terjadi sebaliknya.

Untuk menentukan derajat kebebasan dipergunakan rumus sebagai berikut : 


$$
\mathrm{v}=\frac{\left(\mathrm{s}_{1}{ }^{2} / \mathrm{n}_{1}+\mathrm{s}_{2}{ }^{2} / \mathrm{n}_{2}\right)^{2}}{\frac{\left(\mathrm{s}_{1}{ }^{2} / \mathrm{n}_{1}\right)^{2}}{\mathrm{n}_{1}-1}+\frac{\left(\mathrm{s}_{2}{ }^{2} / \mathrm{n}_{2}\right)^{2}}{\mathrm{n}_{2}-1}}
$$

[Ronald E. Walpole ; $1986 ; 270$ ]

\section{Uji Pihak Kiri}

Perumusan hipotesis $\mathrm{H}_{0}$ dan hipotesis tandingan $\mathrm{H}_{1}$ untuk pihak kiri adalah :

$$
\left\{\begin{array}{l}
\mathrm{H}_{0}: \mu_{1}=\mu_{2} \\
\mathrm{H}_{1}: \mu_{1}<\mu_{2}
\end{array}\right.
$$

Langkah-langkah yang ditempuh dalam hal ini sejalan dengan yang dilakukan untuk uji pihak kanan.

Jika $\sigma_{1}=\sigma_{2}$, kedua-duanya nilainya tidak diketahui, maka digunakan statistik $\mathrm{t}$ dalam rumus :

$$
t=\frac{\bar{x}_{1}-\bar{x}_{2}}{s \sqrt{\frac{1}{n_{1}}+\frac{1}{n_{2}}}}
$$

Kriteria pengujiannya ialah : Tolak $\mathrm{H}_{0}$ jika $\mathrm{t}$ $\leqslant-t_{1}-\alpha$, dimana $t_{1}{ }_{-\alpha}$ didapat dari daftar ditribusi t dengan $\mathrm{dk}=\left(\mathrm{n}_{1}+\mathrm{n}_{2}-2\right)$ dan peluang $(1-\alpha)$. Untuk harga-harga t lainnya, $\mathrm{H}_{0}$ diterima.

Jika $\sigma_{1} \neq \sigma_{2}$, maka yang digunakan adalah statistik t' dalam rumus :

$$
t^{\prime}=\frac{\bar{x}_{1}-\bar{x}_{2}}{\sqrt{\frac{s_{1}^{2}}{n_{1}}+\frac{s_{2}^{2}}{n_{2}}}}
$$

dan tolak $\mathrm{H}_{0}$ untuk :

$$
\mathrm{t}^{\prime} \leq \frac{\mathrm{w}_{1} \mathrm{t}_{1}+\mathrm{w}_{2} \mathrm{t}_{2}}{\mathrm{w}_{1}+\mathrm{w}_{2}}
$$

dimana $w_{1}, w_{2}, t_{1}$ dan $t_{2}$ semuanya seperti telah diuraikan di muka. Jika t' lebih besar dari harga tersebut, maka $\mathrm{H}_{0}$ diterima.

\section{Keterangan :}

$\overline{\mathrm{x}} \quad$ : nilai rata-rata hasil penelitian berdasarkan dugaan

$\mu_{0} \quad$ : nilai rata-rata awal sebelum penelitian

$\sigma \quad$ : simpanga baku / standart deviasi

n : jumlah sample yang diteliti

$\alpha \quad$ : taraf nyata/taraf signifikan

(misal : $\alpha=0,05$, maka taraf nyata $=5 \%$, berarti kira-kira 5 dari setiap kesimpulan akan menolak hipotesis yang seharusnya diterima)

\section{METODOLOGI PENELITIAN}

\section{Jenis Data yang Diperlukan}

Data yang diperlukan untuk analisa adalah : Nama obat, lot obat yang tersedia, harga satuan obat, peletakan obat, sistem penerimaan resei dokter, pengeluaran obat, satuan obat, dan hal-hal lain yang berhubungan dengan kegiatan pelayanan obat

\section{Tahapan Pengolahan Data}

1. Menghitung waktu pelayanan sebelum penerapan SIM 
2. Menghitung waktu pelayanan sesudah penerapan SIM

3. Melakukan uji selisih dua rataan
Untuk memperjelas feed back dari penulisan tugas akhir ini, maka penulis mencantumkan flow chart sebagaimana tampak di bawah ini :
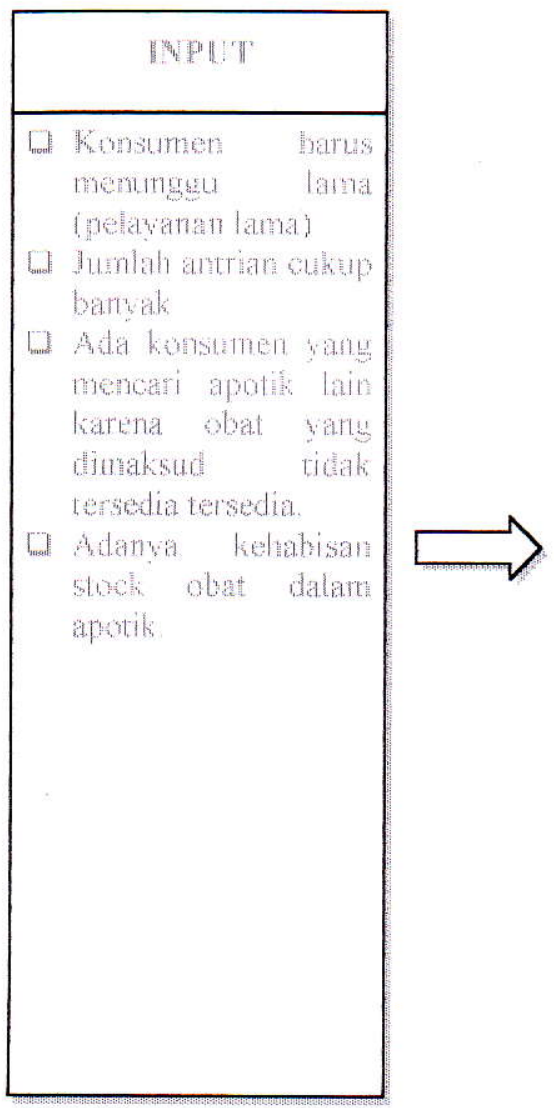

\begin{tabular}{|c|c|}
\hline & 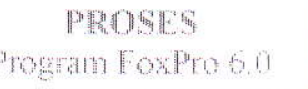 \\
\hline & $\begin{array}{l}\text { Harga satuan obat, } \\
\text { lokasi obat dalam } \\
\text { penyimpanan, dan } \\
\text { total harga yang } \\
\text { harus dibayar } \\
\text { konsumen secara } \\
\text { otomatis dapat } \\
\text { diketahui dengan } \\
\text { hanya mengetikkan } \\
\text { abjad awal nama } \\
\text { obat yang dimaksud. }\end{array}$ \\
\hline & $\begin{array}{l}\text { Jaringan informasi } \\
\text { otomatis dari } \\
\text { transaksi pembelian } \\
\text { obat dengan arsip } \\
\text { laporan distribusi } \\
\text { obat dalam apotik. }\end{array}$ \\
\hline & $\begin{array}{l}\text { Data stock obat } \\
\text { diketahui secara } \\
\text { otomatis jika ada } \\
\text { transaksi penjualan } \\
\text { obat yang terjadi. }\end{array}$ \\
\hline
\end{tabular}

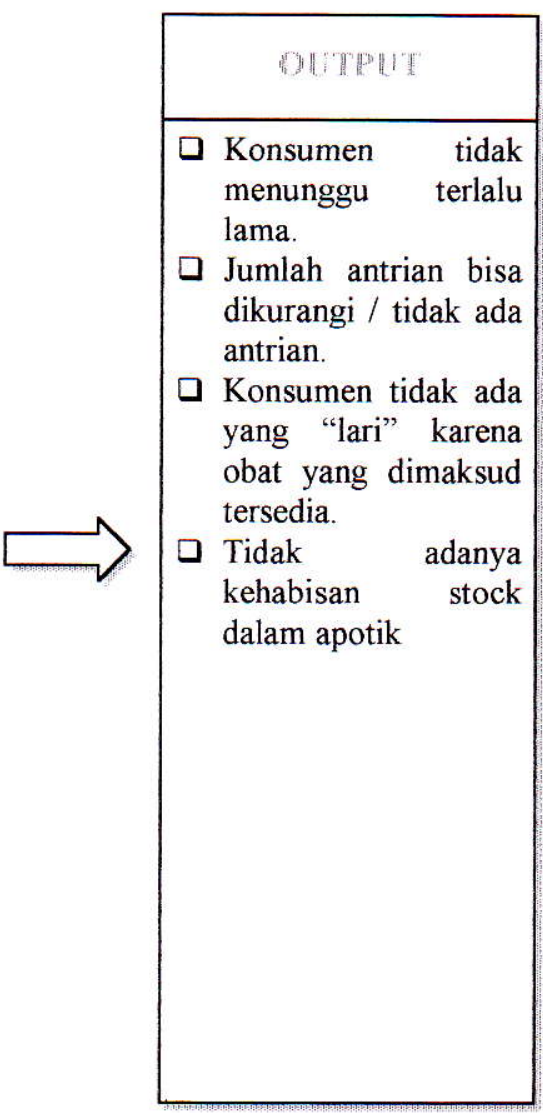

\section{Gambar 3}

Flow Chart Feed Back Penulisan Tugas Akhir

\section{HASIL DAN PEMBAHASAN}

Dari hasil analisa yang telah dilakukan, maka didapat hasil sebagai berikut :

\section{Waktu Pelayanan Sebelum Penerapan SIM}

Tabel 1

\section{Waktu Pelayanan Sebelum Penerapan SIM}

\begin{tabular}{|c|c|c|c|}
\hline No. & $\begin{array}{c}\text { Kegiatan } \\
\text { Pelayanan }\end{array}$ & $\begin{array}{c}\text { Waktu } \\
\text { Pelayanan } \\
\text { (menit) }\end{array}$ & $\begin{array}{c}\text { Waktu yang dibutuhkan untuk } \\
\text { pelayanan 1 resep/1 obat } \\
\text { (menit) }\end{array}$ \\
\hline 1 & 1 resep / 3 obat & 33 & 11.0 \\
\hline 2 & 1 resep / 2 obat & 26 & 13.0 \\
\hline 3 & 1 resep / obat & 24 & 12.0 \\
\hline
\end{tabular}




\begin{tabular}{|c|c|c|c|}
\hline 4 & 1 resep $/ 1$ obat & 12 & 12.0 \\
\hline 5 & 1 resep / 3 obat & 35 & 11.7 \\
\hline 6 & 1 resep $/ 2$ obat & 20 & 10.0 \\
\hline 7 & 1 resep / 1 obat & 13 & 13.0 \\
\hline 8 & 1 resep $/ 2$ obat & 20 & 10.0 \\
\hline 9 & 1 resep $/ 2$ obat & 23 & 11.5 \\
\hline 10 & 1 resep $/ 3$ obat & 34 & 11.3 \\
\hline 11 & 1 resep $/ 1$ obat & 12 & 12.0 \\
\hline 12 & I resep / I obat & 15 & 15.0 \\
\hline 13 & 1 resep / 3 obat & 31 & 10.3 \\
\hline 14 & 1 resep / 3 obat & 32 & 10.7 \\
\hline 15 & 1 resep / 1 obat & 12 & 12.0 \\
\hline 16 & 1 resep / I obat & 13 & 13.0 \\
\hline 17 & 1 resep $/ 2$ obat & 23 & 11.5 \\
\hline 18 & 1 resep / 1 obat & 11 & 11.0 \\
\hline 19 & 1 resep $/ 2$ obat & 24 & 12.0 \\
\hline \multicolumn{3}{|c|}{$\Sigma$ waktu pelayanan untuk 1 resep/l obat } & 223.0 \\
\hline \multicolumn{3}{|c|}{ Rata-rata waktu pelayanan 1 resep/l obat } & 11.7 \\
\hline
\end{tabular}

\section{Waktu Pelayanan Sesudah Penerapan SIM Berbasis Komputer}

Tabel 2

Waktu Pelayanan Dengan Penerapan SIM

\begin{tabular}{|c|c|c|c|c|c|}
\hline No. & $\begin{array}{c}\text { Jumlah } \\
\text { Kedatangan }\end{array}$ & $\begin{array}{l}\text { Kegiatan } \\
\text { Pelayanan }\end{array}$ & $\begin{array}{c}\text { Waktu } \\
\text { Pelayanan }\end{array}$ & $\begin{array}{l}\text { Pelayanan } \\
1 \mathrm{rsp} / 1 \text { obt }\end{array}$ & Keterangan \\
\hline 1. & 2 & 1 resep / 3 obat & 6 menit & 2 menit & Melayani konsumen ke - 1 \\
\hline 2. & 1 & 1 resep / 2 obat & 4.2 menit & 2.1 menit & Melayani konsumen ke - 2 \\
\hline 3. & 1 & 1 resep / 2 obat & 4.5 menit & 2.25 menit & Melayani konsumen ke - 3 \\
\hline 4. & 2 & 1 resep / 1 obat & 4 menit & 4 menit & Melayani konsumen ke- 4 \\
\hline 5. & 1 & 1 resep / 3 obat & 5.8 menit & 1.93 menit & Melayani konsumen ke-5 \\
\hline 6. & 2 & 1 resep / 2 obat & 5 menit & 2.5 menit & Melayani konsumen ke -6 \\
\hline 7. & 2 & 1 resep / 1 obat & 3 menit & 3 menit & Melayani konsumen ke-7 \\
\hline 8. & 1 & 1 resep $/ 2$ obat & 4.2 menit & 2.1 menit & Melayani konsumen $\mathrm{ke}-8$ \\
\hline 9. & 1 & 1 resep / 2 obat & 3.8 menit & 1.9 menit & Melayani konsumen ke-9 \\
\hline 10. & 3 & 1 resep / 3 obat & 6 menit & 2 menit & Melayani konsumen ke - 10 \\
\hline 11. & 1 & 1 resep / 1 obat & 4 menit & 4 menit & Melayani konsumen ke - 11 \\
\hline 12. & 1 & 1 resep / 1 obat & 3.4 menit & 3.4 menit & Melayani konsumen ke - 12 \\
\hline 13. & 1 & 1 resep / 3 obat & 5 menit & 1.67 menit & Melayani konsumen ke - 13 \\
\hline 14. & 1 & 1 resep / 3 obat & 5.2 menit & 1.73 menit & Melayani konsumen ke- 14 \\
\hline 15. & 2 & 1 resep / 1 obat & 3 menit & 3 menit & Melayani konsumen ke - 15 \\
\hline 16. & 1 & 1 resep / 1 obat & 3.6 menit & 3.6 menit & Melayani konsumen ke - 16 \\
\hline 17. & 2 & 1 resep / 2 obat & 4 menit & 2 menit & Melayani konsumen ke - 17 \\
\hline 18. & 1 & 1 resep $/ 1$ obat & 2.7 menit & 2.7 menit & Melayani konsumen ke - 18 \\
\hline 19. & 1 & 1 resep / 2 obat & 3.8 menit & 1.9 menit & Melayani konsumen ke - 19 \\
\hline$\Sigma$ & 27 & & $81.2 \mathrm{mnt}$ & $47.78 \mathrm{mnt}$ & \\
\hline
\end{tabular}


Dari tabel di atas, maka dapat diketahui bahwa dengan mempergunakan bantuan software Foxpro for Windows, dalam waktu 81.2 menit 19 konsumen dapat dilayani. Padahal dari perhitungan sebelumnya, jika pelayanan dilakukan secara manual memerlukan waktu 413 menit untuk 19 konsumen. Dengan demikian dapat dikatakan bahwa jika semula pelayanan yang dilakukan secara manual dapat mengakibatkan tidak terlayaninya kurang lebih 8 konsumen, maka dengan mempergunakan bantuan software komputer, seluruh konsumen yang datang dapat terlayani. Apabila suatu saat nantinya jumlah konsumen yang datang lebih banyak dari pada waktu pengamatan, maka kalaupun terjadi antrian, maka konsumen tidak akan menunggu dalam waktu yang terlalu lama.

Simulasi aplikasi rancangan sistem informasi ini diusahakan menyamai dengan keadaan yang nyata dengan mempertimbangkan beberapa hal yang mempengaruhi waktu pelayanan staf apotik, maka dalam hal ini waktu pelayanan dengan bantuan program komputer tersebut ditambah dengan allowance. Adapun allowance di sini ditujukan untuk memberikan kelonggaran waktu rata-rata yang dibutuhkan oleh staf apotik seperti :

- Waktu untuk mencari dan mengambil obat dalam rak 1 menit

- Waktu untuk membuat print out slip pembayaran 2 menit

a Waktu untuk melayani transaksi pembayaran konsumen 1 menit
Dari Tabel di atas dapat dihitung bahwa rata-rata waktu pelayanan dengan mempergunakan bantuan software Foxpro for Windows untuk 1 resep/ 1 obat adalah :

$$
\frac{47.78}{19}=2.51 \text { menit }
$$

Dengan mempertimbangkan allowance sebagaimana telah diuraikan di atas, maka dapat dikatakan bahwa waktu yang dibutuhkan untuk melayani konsumen dengan mempergunakan bantuan software Foxpro for Windows adalah :

2.51 menit +4 menit $=6.51$ menit

\section{Uji Selisih Dua Rataan : Uji Satu Pihak Waktu Pelayanan Sebelum dan Sesudah Penerapan SIM Berbasis Komputer}

Karena umumnya besar $\sigma_{1}$ dan $\sigma_{2}$ tidak diketahui, maka di sini akan diasumsikan bahwa keadaan $\sigma_{1} \neq \sigma_{2}$ dan statistik yang digunakan di sini adalah :

$$
t^{\prime}=\frac{\bar{x}_{1}-\bar{x}_{2}}{\sqrt{\frac{s_{1}^{2}}{n_{1}}+\frac{s_{2}^{2}}{n_{2}}}}
$$

dalam hal ini kriteria pengujian adalah : tolak hipotesis $\mathrm{H}_{0}$ jika $\mathrm{t}^{\prime} \geq \mathrm{t}_{\text {tabel }}$ dan terima $\mathrm{H}_{0}$ jika terjadi sebaliknya.

Untuk menentukan derajat kebebasan dipergunakan rumus sebagai berikut :

$$
\mathrm{v}=\frac{\left(\mathrm{s}_{1}{ }^{2} / \mathrm{n}_{1}+\mathrm{s}_{2}{ }^{2} / \mathrm{n}_{2}\right)^{2}}{\frac{\left(\mathrm{s}_{1}{ }^{2} / \mathrm{n}_{1}\right)^{2}}{\mathrm{n}_{1}-1}+\frac{\left(\mathrm{s}_{2}{ }^{2} / \mathrm{n}_{2}\right)^{2}}{\mathrm{n}_{2}-1}}
$$

sedangkan untuk menghitung taksiran simapangan baku $s_{1}$ dan $s_{2}$ yang dihitung 
dari sampel pengamatan, dipergunakan rumus sebagai berikut :

$$
\mathrm{s}^{2}=\frac{\sum\left(\mathrm{x}_{\mathrm{i}}-\overline{\mathrm{x}}\right)^{2}}{\mathrm{n}-1}
$$

Untuk mempermudah pengujian ini, tabel hasil pengamatan kembali disederhanakan. Sebagimana perhitungan sebelumnya, maka untuk kepentingan ini pun dipergunakan bantuan software Microsoft Excel sebagaimana tertera pada Tabel di bawah ini :

Tabel 3

Perhitungan Statistik Waktu Pelayanan Sebelum Penerapan SIM

\begin{tabular}{|c|c|c|c|}
\hline No. & $\begin{array}{c}\text { Waktu } \\
\text { pelayanan }\left(\mathrm{x}_{\mathrm{i}}\right)\end{array}$ & $\mathrm{x}_{\mathrm{i}}-\overline{\mathrm{x}}$ & $\left(\mathrm{x}_{\mathrm{i}}-\overline{\mathrm{x}}\right)^{2}$ \\
\hline 1 & 11.0 & -0.7 & 0.54 \\
\hline 2 & 13.0 & 1.3 & 1.60 \\
\hline 3 & 12.0 & 0.3 & 0.07 \\
\hline 4 & 12.0 & 0.3 & 0.07 \\
\hline 5 & 11.7 & -0.1 & 0.00 \\
\hline 6 & 10.0 & -1.7 & 3.02 \\
\hline 7 & 13.0 & 1.3 & 1.60 \\
\hline 8 & 10.0 & -1.7 & 3.02 \\
\hline 9 & 11.5 & -0.2 & 0.06 \\
\hline 10 & 11.3 & -0.4 & 0.16 \\
\hline 11 & 12.0 & 0.3 & 0.07 \\
\hline 12 & 15.0 & 3.3 & 10.65 \\
\hline 13 & 10.3 & -1.4 & 1.97 \\
\hline 14 & 10.7 & -1.1 & 1.15 \\
\hline 15 & 12.0 & 0.3 & 0.07 \\
\hline 16 & 13.0 & 1.3 & 1.60 \\
\hline 17 & 11.5 & -0.2 & 0.06 \\
\hline 18 & 11.0 & -0.7 & 0.54 \\
\hline 19 & 12.0 & 0.3 & 0.07 \\
\hline & $\Sigma\left(\mathrm{x}_{\mathrm{i}}-\overline{\mathrm{x}}\right)^{2}$ & & 26.30 \\
\hline
\end{tabular}

Sebagaimana telah diketahui jumlah data dalam pengumpulan data adalah sebesar $19(\mathrm{n}=19)$, sehingga simpangan bakunya $\left(\mathrm{s}_{1}{ }^{2}\right)$ adalah : (dalam perhitungan ini dipergunakan bantuan software Microsoft Excel)

$$
\begin{aligned}
\mathrm{s}_{1}^{2} & =\frac{\sum\left(\mathrm{x}_{\mathrm{i}}-\overline{\mathrm{x}}\right)^{2}}{\mathrm{n}-1} \\
& =\frac{26.30}{19-1} \\
& =1.46
\end{aligned}
$$

Sedangkan untuk menghitung simpangan baku $s_{2}$ sesudah penerapan SIM berbasis komputer, maka dipergunakan tabel berikut :

\begin{tabular}{|c|c|c|c|}
\hline No. & $\begin{array}{c}\text { Waktu } \\
\text { pelayanan }\left(\mathrm{x}_{\mathbf{l}}\right)\end{array}$ & $x_{i}-\bar{X}$ & $\left(x_{i}-\bar{X}\right)^{2}$ \\
\hline 1 & 6 & -0.51 & 0.2601 \\
\hline 2 & 4.2 & -2.31 & 5.3361 \\
\hline 3 & 4.5 & -2.01 & 4.0401 \\
\hline 4 & 4 & -2.51 & 6.3001 \\
\hline 5 & 5.8 & -0.71 & 0.5041 \\
\hline 6 & 5 & -1.51 & 2.2801 \\
\hline 7 & 3 & -3.51 & 12.3201 \\
\hline 8 & 4.2 & -2.31 & 5.3361 \\
\hline 9 & 3.8 & -2.71 & 7.3441 \\
\hline 10 & 6 & -0.51 & 0.2601 \\
\hline 11 & 4 & -2.51 & 6.3001 \\
\hline 12 & 3.4 & -3.11 & 9.6721 \\
\hline 13 & 5 & -1.51 & 2.2801 \\
\hline 14 & 5.2 & -1.31 & 1.7161 \\
\hline 15 & 3 & -3.51 & 12.3201 \\
\hline 16 & 3.6 & -2.91 & 8.4681 \\
\hline 17 & 4 & -2.51 & 6.3001 \\
\hline 18 & 2.7 & -3.81 & 14.5161 \\
\hline 19 & 3.8 & -2.71 & 7.3441 \\
\hline \multicolumn{3}{|c|}{$\Sigma\left(x_{i}-\bar{X}\right)^{2}$} & 112.8979 \\
\hline
\end{tabular}

Tabel 4

Perhitungan Statistik Waktu Pelayanan Sesudah Penerapan SIM

Sebagaimana telah diketahui pula bahwa jumlah data sesudah penerapan SIM berbasis komputer ini sama besar dengan pengumpulan data sebelum penerapan SIM agar mendekati keadaan riilnya, yaitu sebesar $19(\mathrm{n}=19)$, sehingga simpangan bakunya $\left(\mathrm{s}_{2}{ }^{2}\right)$ adalah : (dalam perhitungan ini juga dipergunakan bantuan software Microsoft Excel)

$$
s_{1}{ }^{2}=\frac{\sum\left(x_{i}-\bar{x}\right)^{2}}{n-1}
$$


$=\frac{112.8979}{19-1}$

$=6.27$

Sehingga dengan :

$\overline{\mathrm{x}}_{1}=11.7 ; \quad \overline{\mathrm{x}}_{2}=6.51 ; \quad \mathrm{s}_{1}{ }^{2}=1.46$

$; \mathrm{s}_{2}{ }^{2}=6.27 ; \mathrm{n}_{1}=19 ; \mathrm{n}_{2}=19$

maka : (untuk menghitung 't' ini juga memakai bantuan software Microsoft Excel)

$$
\begin{aligned}
t^{\prime} & =\frac{\bar{x}_{1}-\bar{x}_{2}}{\sqrt{\frac{s_{1}^{2}}{n_{1}}+\frac{s_{2}^{2}}{n_{2}}}} \\
& =\frac{11.7-6.51}{\sqrt{\frac{1.46}{19}+\frac{6.27}{19}}} \\
& =8.14
\end{aligned}
$$

Sebagaimana telah dikemukakan sebelumnya bahwa derajat kebebasan untuk daftar distribusi t (terlampir) adalah : (dalam perhitungan derajat kebebasan ini dibantu dengan software Microsoft Excel)

$$
\begin{aligned}
\mathrm{v} & =\frac{\left(\mathrm{s}_{1}{ }^{2} / \mathrm{n}_{1}+\mathrm{s}_{2}{ }^{2} / \mathrm{n}_{2}\right)^{2}}{\frac{\left(\mathrm{s}_{1}{ }^{2} / \mathrm{n}_{1}\right)^{2}}{\mathrm{n}_{1}-1}+\frac{\left(\mathrm{s}_{2}{ }^{2} / \mathrm{n}_{2}\right)^{2}}{\mathrm{n}_{2}-1}} \\
= & \frac{((1.46 / 19)+(6.27 / 19))^{2}}{\frac{(1.46 / 19)^{2}}{19-1}+\frac{(6.27 / 19)^{2}}{19-1}} \\
= & 26
\end{aligned}
$$

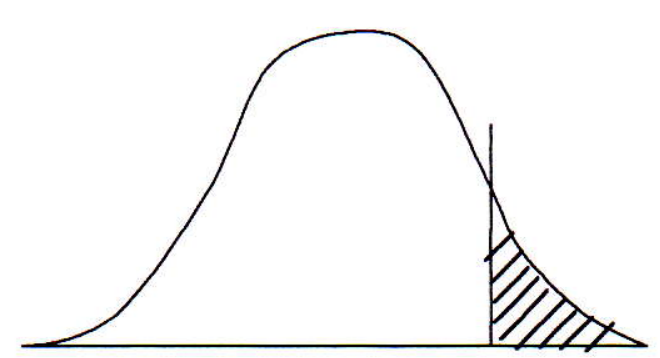

Grafik Sketsa Distribusi t

\section{KESIMPULAN}

1. Kriteria pengujian adalah : terima hipotesis $\mathrm{H}_{0}$ jika $\mathrm{t}$ hitung lebih kecil dengan $\mathrm{t}_{\text {tabel }}$,yaitu 1.71 (jumlah waktu pelayanan sebelum dan sesudah penerapan SIM berbasis komputer adalah sama atau, adanya penerapan SIM berbasis komputer tidak mempengaruhi jumlah waktu pelayanan), dan tolak $\mathrm{H}_{0}$ dalam hal lainnya (jumlah waktu pelayanan sebelum penerapan SIM berbasis komputer lebih besar daripada jumlah waktu pelayanan sesudah penerapan SIM berbasis komputer).

2. Dalam hal ini diketahui bahwa dari penelitian memberikan hasil hitung $=8.14$, dan ini jatuh pada daerah penolakan $\mathrm{H}_{0}$ (sebagaimana tertera pada Gambar 5 - 1). Jadi hipotesis $\mathrm{H}_{0}$ ditolak. Dan itu artinya adalah bahwa penerapan SIM berbasis komputer dapat dikatakan akan dapat mengurangi besarnya waktu pelayanan staf apotik daripada sebelum penerapan SIM berbasis komputer. 


\section{DAFTAR PUSTAKA}

Davis B. Gordon, 1998, Pengantar Sistem Informasi Manajemen, PT. Pustaka Binaman Pressindo - Jakarta.

Davis B. Gordon, 1996, Perancangan Sistem Informasi Manajemen, PT. Pustaka Binaman Pressindo - Jakarta.

D. Suryandi H.S dan Bunawan, 1996,

Siklus Pengembangan Sistem Informasi, Penerbit Gunadarma Jakarta.

Diki Septanto, 1995, Panduan Berilustrasi Foxpro for Windows, Andi Offset Yogyakarta.

Ronald E. Walpole, 1986, Ilmu Peluang dan Statistika Untuk Insinyur dan Ilmuan, ITB Bandung 